\title{
Gorlin-Goltz-szindrómás beteg komplex fogorvosi, szájsebészeti kezelése és 8 éves követése
}

\author{
Gurdán Zsuzsanna dr. ${ }^{1}$ - Gelencsér Gábor dr. ${ }^{2}$ \\ Lengyel Zsuzsanna dr. ${ }^{3}$. Szalma József $\mathrm{dr}^{2}$ \\ ${ }^{1}$ Pécsi Tudományegyetem, Klinikai Központ, Fogorvostudományi Kar, \\ Gyermek- és Ifjúsági Fogászati Tanszék, Pécs \\ ${ }^{2}$ Pécsi Tudományegyetem, Klinikai Központ, Fogorvostudományi Kar, \\ Arc-, Állcsont- és Szájsebészeti Tanszék, Pécs \\ ${ }^{3}$ Pécsi Tudományegyetem, Klinikai Központ, Általános Orvostudományi Kar, \\ Bőr-, Nemikórtani és Onkodermatológiai Klinika, Pécs
}

\begin{abstract}
A Gorlin-Goltz-szindróma autoszomális dominánsan öröklődő kórkép. Vezető tünetei az állcsontok keratocystái, a multiplex basaliomák, csontvázfejlődési rendellenességek, intracranialis calcificatio és tenyéri, talpi dyskeratosis. A szindróma egyik leggyakoribb és sokszor először észrevehető tünete az állcsonti keratocysta. A szerzők munkájukban egy fogszabályozó osztályon diagnosztizált és kezelt gyermek esetét mutatják be. A betegség ritka előfordulása ellenére fontos a korai, fiatalkorban történő felismerés. A betegek rendszeres gondozásával megelőzhetők az akár életet veszélyeztető elváltozások és a radikális mútéttel járó kezelések.

Orv Hetil. 2020; 161(2): 67-74.
\end{abstract}

Kulcsszavak: multiplex basalioma, Gorlin-Goltz-szindróma, odontogen keratocysta, keratocysticus odontogen daganat

\section{The complex dental and oral surgical management with 8-year follow up of a Gorlin-Goltz syndrome patient}

Gorlin-Goltz syndrome is an autosomal dominant hereditary disease. Its leading symptoms include keratocysts of the jaws, multiple basal cell carcinomas, skeletal abnormalities, intracranial calcifications and dyskeratosis of the soles and palms. One of the most common and often firstly discovered symptoms is the single or multiplex keratocysts of the jaws. The authors present a case of a child, diagnosed in their orthodontic department. Despite the rare occurrence of the disease, an early detection is important, especially in young patients. Regular follow-up and timely care for patients may avoid life-threatening malformations and radical surgical treatments.

Keywords: multiple basalioma, Gorlin-Goltz syndrome, odontogenic keratocyst, odontogenic keratocystic tumor

Gurdán Zs, Gelencsér G, Lengyel Zs, Szalma J. [The complex dental and oral surgical management with 8-year follow up of a Gorlin-Goltz syndrome patient]. Orv Hetil. 2020; 161(2): 67-74.

(Beérkezett: 2019. június 27.; elfogadva: 2019. augusztus 5.)

\section{Rövidítések}

CBCT $=($ cone-beam CT) kúpsugaras CT; CT $=($ computed tomography) számítógépes tomográfia; $\mathrm{MR}=$ mágneses rezonancia; NSN = naevussejtes naevus; OP = ortopantomogram; PTCH-gén = humán homológ Drosophila patched gén; SMO $=($ smoothened protein $)$ simított fehérje; $\mathrm{WHO}=$ (World Health Organization) Egészségügyi Világszervezet
A szindrómát Gorlin és Goltzírták le 1960-ban [1], mely egy autoszomális dominánsan öröklődő, praecancerosus állapotot jelentő szindróma. A betegek a tumorszuppresszor PTCH-gén egyik alléljának mutációját öröklik, emiatt bármilyen környezeti hatás (például irradiáció) következtében megszúnik a PTCH gén tumorszuppreszszor hatása, kontrollálatlanná válik a sejtciklus [2]. 
A génnek számos mutációja ismert, melyek a GorlinGoltz-szindróma mellett felelősek lehetnek meningeoma, oesophagus- és húgyhólyag-laphámcarcinoma kialakulásáért is [3]. A betegség hátterében álló PTCH-génnek - amely a 'hedgehog' szignáltranszdukciós útvonal egy tumorszuppresszor génje - a mutációját sporadikus basaliomák esetében is igazolták. A Gorlin-Goltz-szindróma basalsejtes naevus szindróma vagy naevoid basalsejtes carcinoma szindróma néven is megtalálható a szakirodalomban $[4,5]$. Jól meghatározható kritériumrendszerrel diagnosztizálható. A diagnózis akkor állítható fel, ha két vezető tünet [6] vagy egy vezető és két járulékos tünet jelentkezik (1. táblázat) $[7,8]$.

A diagnózis felállításában kitüntetett szerepe van a fizikális vizsgálat mellett a radiológiai eljárások elvégzésének. A Gorlin-Goltz-szindróma egyik vezető tünetére, az állcsontok keratocystáira jellemző a panasz nélküli megjelenés és növekedés az állcsontokban. Kontroll radiológiai felvétel során észrevett keratocysta, illetve a fizikális vizsgálat alkalmával tapasztalt arcaszimmetria és a fogak meglazulása hívhatja fel a figyelmet a szindróma megjelenésére. A keratocysták agresszív és visszatérő, gyakran recidiváló tulajdonsága miatt a tumor elnevezéssel illették 2005-ben [9]. 2017-ben a WHO visszaállította az odontogen keratocysta megnevezést, számos kritika kíséretében $[10,11]$. Jellemző a 20-40 éves életkor közötti megjelenés a mandibulában elhelyezkedve, elsősorban a bölcsességfogak régiójában $[12,13]$. Khaliq és mtsai 11 éves vizsgálati periódusában 15 páciensnél diagnosztizálták a Gorlin-Goltz-szindrómát. A páciensek 57\%-a 10-19 éves, 43\%-a pedig a 20-29 éves korcsoportba esett. Mindegyiküknél megfigyelhető volt a keratocysticus odontogen elváltozás, mely elsősorban (77\%ban) a mandibula területére lokalizálódott [14].

1. táblázat |A Gorlin-Goltz-szindróma diagnózisának felállításához szükséges vezető és járulékos tünetek

\begin{tabular}{l}
\hline Vezető tünetek \\
\hline 1. Multiplex basaliomák vagy egy basalioma 30 éves kor alatt \\
2. Állcsonti keratocysta \\
3. Palmaris/plantaris dyskeratosis \\
4. Lamellaris vagy 20 éves kor alatt jelentkező falx cerebri calcificatio \\
5. Pozitív családi anamnézis
\end{tabular}

Járulékos tünetek

1. Veleszületett vázrendszeri fejlődési rendellenesség: bifid, összenőtt, hiányzó bordák vagy csigolyák

2. Macrocephalia: megnövekedett occipitofrontalis körfogat, elődomborodó homlokkal

3. Cardialis vagy ovariumfibroma

4. Medulloblastoma

5. Lymphomesenterialis cysta

6. Congenitalis malformatiók: ajak-szájpad hasadék, polydactylia, a szem fejlődési rendellenességei (cataracta, coloboma, microphthalmia)
Az állcsontcysták elsődleges ellátásának célja a cystán belüli nyomás csökkentése. A terápia során az enucleatio curettage kiegészítésével vagy a nélkül, illetve a marsupialisatio elvégzése az első lépés. Brondum és Jensen vizsgálati eredménye azonban felhívja a figyelmet, mely szerint az odontogen keratocysták recidívahajlama 25\% [15]. Az enucleatio önmagában nem jelent mindig megfelelő terápiát, amit az odontogen keratocysták vékony, szakadékony falával magyaráznak. Bizonyos irodalmi közlemények szerint az akár $62,5 \%$-os recidívaarány is mutatja, hogy az egy darabban való eltávolítás rendkívül nehéz $[16,17]$. Az eljárás nehézségei miatt az enucleatio kiegészítéseként javasolt a Carnoy-oldat használata. Az oldat $60 \mathrm{ml}$ abszolút etanolból, $30 \mathrm{ml}$ kloroformból és $10 \mathrm{ml}$ jégecetból (tömény ecetsav) áll [18]. Számos vizsgálat támasztja alá ezen kezelési mód hatékonyságát, melynek alkalmazása esetén a recidíva nagy mértékben csökkenthető (akár 2,5\%-ra) [19, 20]. Az odontogen cysták kezelése során fontos az enucleatiót követően az üregben visszamaradt epithelialis residuumok vagy szatellitacysták elpusztítása. A krioterápiát számos helyi agresszív állcsontlaesio - mint az ameloblastoma, osszifikáló fibroma - esetében is kedvező eredménnyel használják. Bár az adagolt folyékony nitrogén mennyisége nehezen kontrollálható a szájüregben, így a következményes duzzanat és nekrózis kiszámíthatatlan, a recidíva mértéke 3-9\% közötti alacsony értéket mutat [21, 22]. A keratocysták végső, legradikálisabb terápiája a szegmentális reszekció (mandibula- vagy maxillaszegment sebészi eltávolítása, melynek során a csont folytonossága megszakad) vagy a marginális reszekció (az intakt laesio eltávolítása, megtartva a csont folytonosságát) [23].

Az odontogen keratocysták kezelési alternatíváit foglalja össze a 2. táblázat.

A szindróma megjelenése a férfiak és a nók esetében hasonló arányt mutat, 1 a 60 000-hez [24-26]. A szindrómában szenvedók számára fontos, hogy tudatában legyenek genetikai rendellenességüknek és annak, hogy daganat kialakulása szempontjából fokozottabb veszélyt jelent számukra bármilyen carcinogen hatás [27]. Bőrtünetként a multiplex basaliomák képezik a szindróma másik jellegzetes, vezető tünetét. Elsődleges, hogy ionizáló és nem ionizáló ultraibolya sugárzásból is csak minimális mennyiség érje a bőrüket. A szolárium használatának teljes mellőzése és a napon tartózkodás is csak körültekintően, megfelelő fényvédelmet alkalmazva ajánlott.

2. táblázat Az odontogen keratocysták kezelési módszerei, a recidíva mértékének feltüntetésével [15-23]

\begin{tabular}{lc}
\hline A kezelés típusa & Recidíva előfordulása \\
\hline Dekompresszió és marsupialisatio & $25 \%$ \\
Enucleatio & $62,5 \%$ \\
Enucleatio + Carnoy-oldat használata & $2,5 \%$ \\
Enucleatio + folyékony nitrogén (krioterápia) & $3-9 \%$ \\
Reszekció & $0 \%$
\end{tabular}


A rendszeres bőrgyógyászati és fogorvosi vizsgálatoknak ezen betegcsoportban kiemelt jelentőségük van, az utóbbiaknak azért, hogy az állcsonti manifesztációk mielőbb felismerésre kerülhessenek. A sikeres terápiában elsődleges szerepe van a szindróma korai felismerésének és a multidiszciplináris ellátás biztosításának.

\section{Esetismertetés}

A 10 éves fiú fogszabályozó kezelés céljából jelentkezett klinikánkon, első alkalommal 2009 novemberében. Anamnézisében általános betegség nem szerepelt. A bal felkaron fél $\mathrm{cm}$-es 'cafe au lait' folt volt látható, illetve kérdésre a háton a gerinc bal oldalán kb. $5 \mathrm{~cm}$-es pigmenthiányos területet is említett. Az arc izomzata szimmetrikus volt, normál tónusú. Távol ülő szemek, dús,

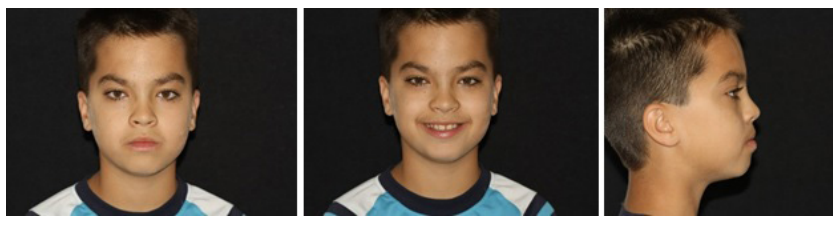

1. ábra $\quad$ A fogszabályozó kezelést megelőző extraoralis fotók, melyeken megfigyelhetôk a távol ülő szemek, a kitelt orrgyök

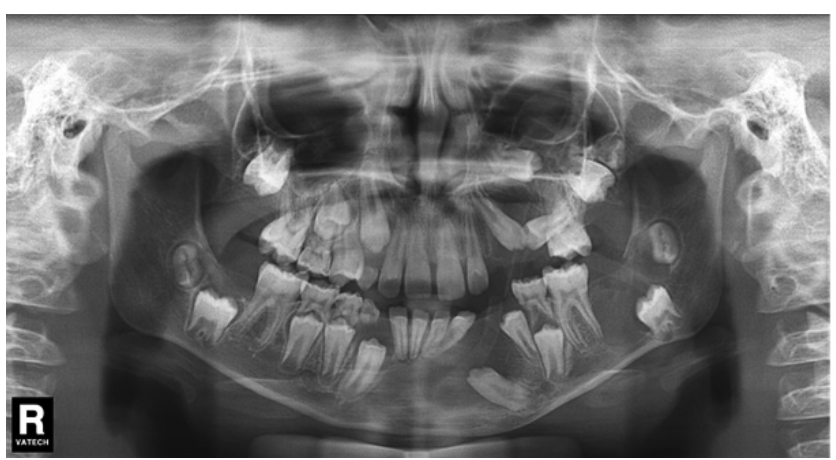

2. ábra

A fogszabályozó kezelést megelőző, 2010 januárjában készült ortopantomogram-felvétel, melyen mindkét állcsontban impaktált fogak és mind a mandibulában (a bal szemfog és a 7-es fog környékén, illetve a frontalis területen), mind a maxillában (a bal felső kisőrlők területe) nagy kiterjedésű cystosus képletek és már a cysták dekompressziója miatt behelyezett dréncsövek láthatók vaskos szemöldök, kitelt orrgyök voltak jellemzők (1. ábra). A nyálkahártya közepesen vértelt, enanthema nem volt. A száj- és garatképletek szabadok, lobmentesek. A nyelv mozgásában nem volt korlátozott.

Az első szakvizsgálat alkalmával, 2009 novemberében az ortodonciai diagnózis felállításának alappillérét képezte az ortopantomogram (OP) és teleröntgen-felvétel készítése. A kiindulási röntgenfelvételek még filmalapúak voltak, melyek elérhetetlenné váltak az elmúlt 10 év során. 2010 januárjában a digitális technikával készített első OP-felvételen már a cysták dekompressziója is látható dréncső segítségével a kiindulási fogazati status mellett (2. ábra). A szilikon dréncső megfelelő rögzítése érdekében ortodonciai gyưrü került felragasztásra a bal alsó elsô molaris fogra (3. ábra). A cystostomiák kivitelezésekor a cystafalakból 3 helyről vett mintákat patológiai elemzésre küldtük. A hisztológiai vizsgálat radicularis cystát igazolt.

$\mathrm{Az}$ OP-röntgenen diagnosztizált nagy kiterjedésű multiplex, feltehetően cysták (jól elhatárolódó, éles szélü radiolucens képletek) miatt további agy- és arckoponyaCT-t kértünk. A CT-felvétel igazolta a maxillában és mandibulában radiolucensen ábrázolódó csonthiányokat, melyeket előzetesen cystának véleményeztünk. A páciens kivizsgálása során más lokalizációjú csont- vagy lágyrész-cysta nem került diagnosztizálásra. Az állcsonti cysták és a fenotípus alapján felmerült a Gorlin-Goltzszindróma lehetősége.

A páciensnél gerinc- és borda-röntgenfelvételek is készültek az esetlegesen társuló csigolya- és bordaelváltozások kizárására. A gerinc röntgenfelvétele alapján a thoracolumbalis szakaszon enyhe ívú, $S$ alakú scoliosis volt látható. Egyéb strukturális eltérés nem volt kimutatható. A bordák röntgenvizsgálata során nem találtunk strukturális elváltozást.

\section{Családi anamnézis}

A családi anamnézis felderítése során az édesapa kórelőzményében 2009 nyarán epilepsziás rosszullétet provokáló bal oldali frontoparietalis meningeoma operáció szerepelt.

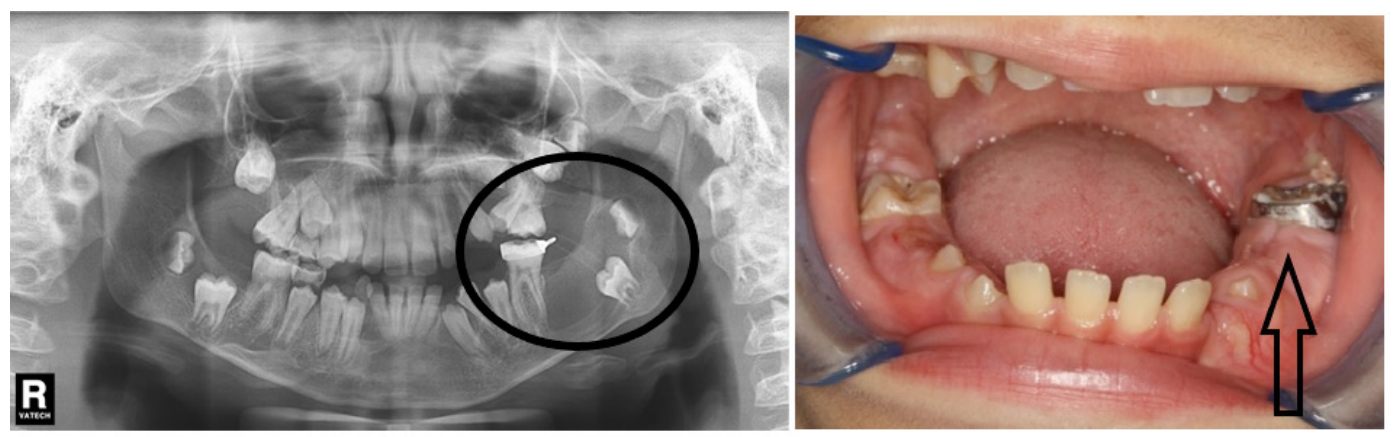

3. ábra $\quad$ A panorámaröntgen-felvétel a cystaszúkítést (dekompresszió dréncsővel) folyamatában mutatja. A bal alsó első molaris fogon található ortodonciai gyürü (nyíl) a dréncső jobb rögzítését szolgálja 


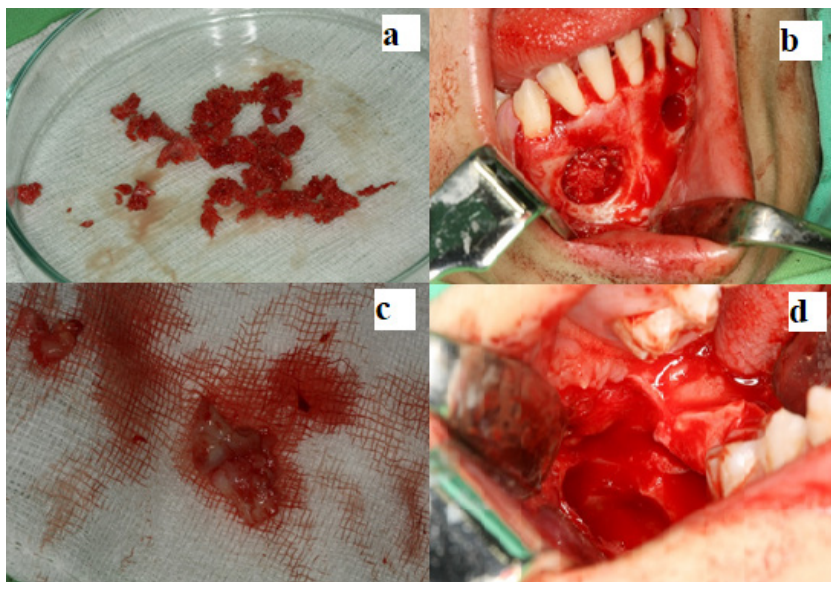

4. ábra a) A képen a csípólapátból nyert spongiosa látható. b) A mandi-
bula bal oldalán az eltávolított cysta helye, a jobb oldali üreg
már spongiosával feltöltve látható. c) A jobb alsó molaris terü-
letról eltávolított cystának imponáló képlet és d) annak a helye
látható az alsó állcsont területén excochleatio után

Az édesapa aztán 8 évvel a fentebb említett bal oldali frontoparietalis meningeoma operációt követően, 2017ben az arcon, a hajas fejbőr területén lévő multiplex basaliomák miatt jelentkezett bőrgyógyászaton. A klinikai megjelenés, valamint a koponya-MR-vizsgálat igazolta a Gorlin-Goltz-szindróma meglétét. A bőrgyógyászati onkoteam döntését követően a betegnél vismodegib $\left(\right.$ Erivedge $^{\circledR}$ )-terápiát indítottak. A betegnél a tumorok komplett remissziója látható folyamatos 'hedgehog'-inhibitor-kezelés mellett.

Betegünknél 2010 októberében, 9 hónap cystaszúkítést követően bal angulustáji cystectomia beavatkozás

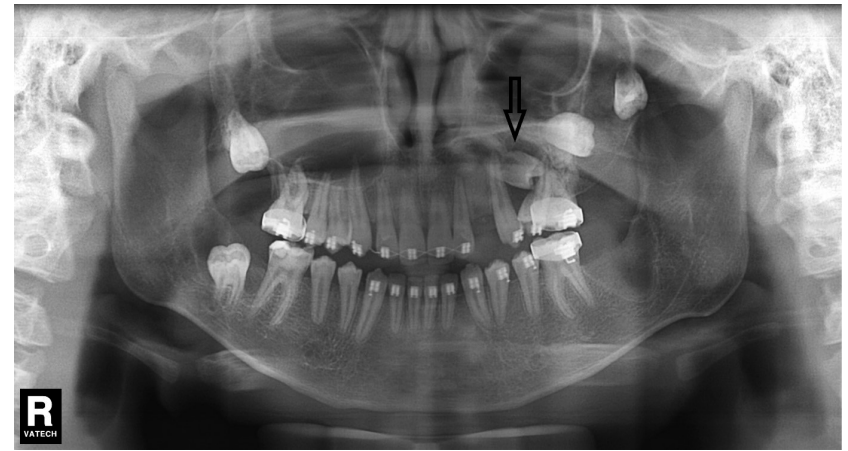

5. ábra

2012-ben készült panorámaröntgen-felvétel, melyen a fogszabályozó kezelés folyamatában látható. A készülék felragasztását követően a bal felső első impaktált kisőrlőfog eltávolítása szükséges volt a kezelés folytatásához (nyíl)

történt, és a hisztológiai vizsgálat során ezúttal a patológus kollégák odontogen keratocystát igazoltak. A műtét során a cystectomia mellett a cystaüregben lévő bal alsó második, harmadik retineált őrlőfogak is eltávolításra kerültek. A sinusba terjedő bal maxillacystát cystectomia és Luc-Caldwell-mútét kíséretében távolítottuk el. A cystafalból származó szövetminta radicularis cystát igazolt.

A mandibula frontalis területének multiplex cystái szintén eltávolításra kerültek, egyidejű autológ csontpótlás mellett (4. ábra). A biológiailag előnyös saját spongiosus csontot a páciens csípőlapátjának vastag falú hátsó ívéből nyertük, ami a fiatal szervezet esetében gyors felépüléssel járt. A cystectomia során eltávolított mưtéti preparátum makroszkópos és mikroszkópos patológiai vizsgálata alapján a jobb és bal alsó kismetsző és szemfog

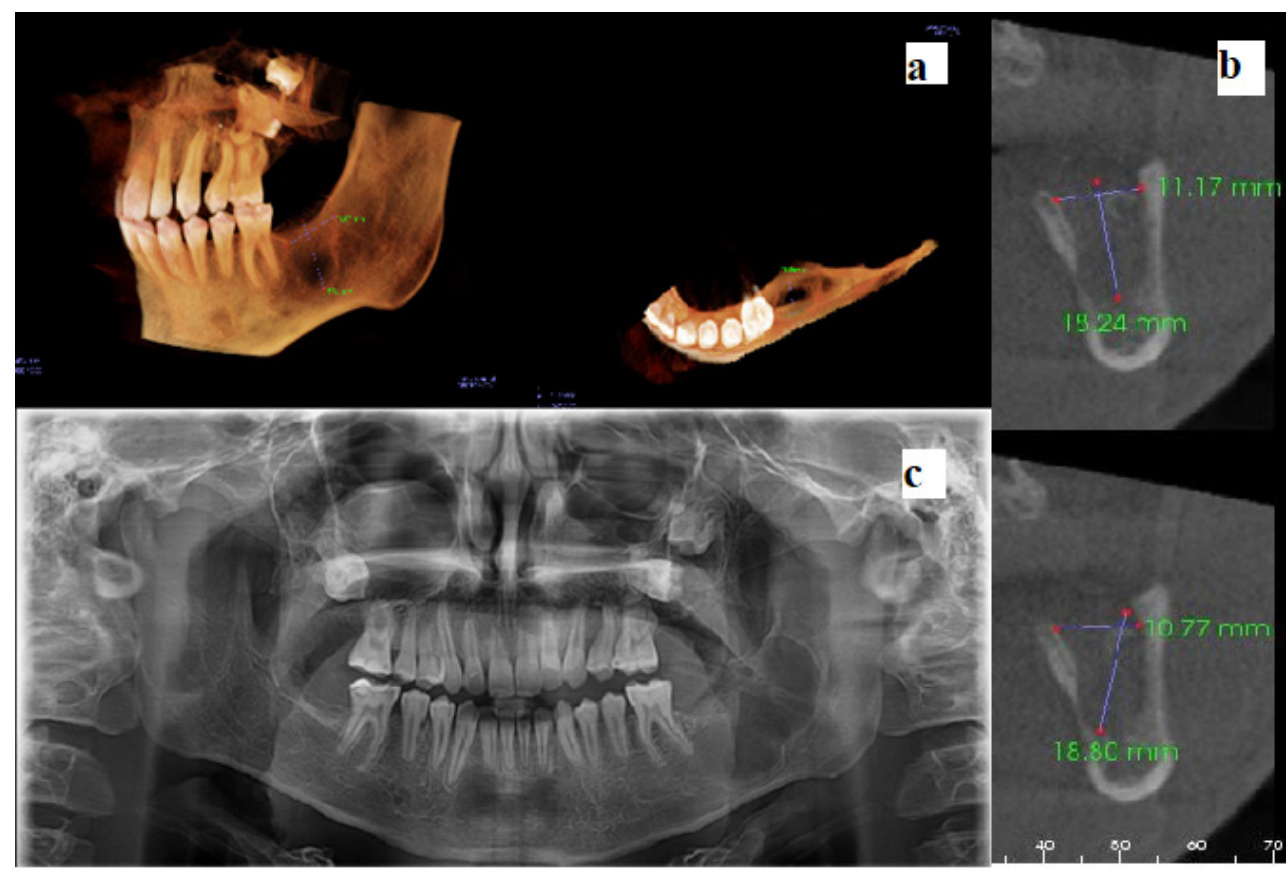

6. ábra

A 2015-ben készült CBCT- és ortopantomogram-felvételen a fogszabályozó kezelés végeredménye látható. a) A CBCT-felvételen a bal angulustáji cysta kiterjedése látható $(11,4 \mathrm{~mm} \times 16 \mathrm{~mm} \times 18,9 \mathrm{~mm})$. b) Az axiális felvételeken jól megítélhető a buccalis és lingualis csontlemezek megtartottsága. c) Az ortodonciai kezelés szövődményeként a felső nagymetszőfogakon gyökérreszorpció alakult ki, továbbá látható a bal angulustájékon a recidív cysta dréndekompressziója 
közötti területből származó minta radicularis cystát, a jobb alsó második és harmadik molaris fog területéról származó kiterjedt cystosus képlet follicularis cystát igazolt.

2011 decemberében megkezdődött a páciens fogszabályozó kezelése is. A kezelési terv alapján az alsó és felső fogívre ragasztott fogszabályozó készülék (equilibrium ${ }^{\circledR}$ bracket, 0.18 slot; Dentaurum, Ispringen, Németország) került felhelyezésre. Az előtörési hajlamot nem mutató bal felső első kisőrlőfog szájsebészeti feltárása, eltávolítása szükségessé vált a szomszédos fogak mozgatásához, sorba állításához (5. ábra).

A fogszabályozó kezelés ideje alatt 2014 februárjában, a mandibula jobb oldali retromolaris területéról a jobb alsó második molaris fog sculptiójára is sor került a nagy kiterjedésû́ csontvesztés és a fog előtörési hajlamának hiánya miatt. A fog környezetében elhelyezkedő, diónyi nagyságú terimét az eltávolítása után patológiai elemzésre küldtük, mely ezúttal odontogen keratocystát igazolt.
2015 októberében, a páciens 16 éves korában a ragasztott fogszabályozó készülék eltávolításra került. A kontroll-CBCT- és -röntgenfelvételen recidiváló bal oldali mandibulacysta miatt (6. ábra) újabb cystectomia elvégzése volt indokolt. A hártyás falú tömlő kimetszését követő mikroszkópos vizsgálat során a belfelszínt változó, több sort meghaladó vastagságú, parakeratoticus többrétegű laphám mutatkozott. A lumenben egy fókuszban „Rushton-testek” voltak elkülöníthetők (7. ábra). A szövettani kép odontogen keratocystának felelt meg. Az újabb cysta kialakulásának megakadályozására a cystectomia kiegészítéseként immáron Carnoyoldatot is használtunk a mütét során.

A 2017-ben, a páciens 18 éves korában végzett bőrgyógyászati szakvizsgálat basaliomára utaló jelet nem talált. Testszerte, illetve a fejtetőn elvétve néhány, 2-6 mm-es, egyenletesen pigmentált NSN (naevussejtes naevus) volt látható. A távol ülő szemek ( 8 . ábra) és a tenyerekben a szurkáltság (palmoplantaris dyskeratosis) felis-
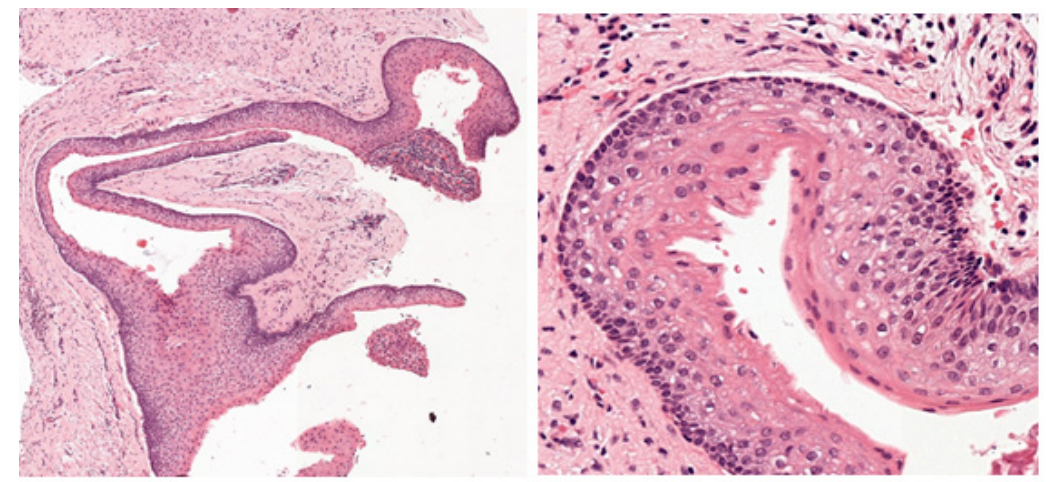

A cysta mandibularis falából származó minta mikroszkópos képén a belfelszínt bélelő parakeratoticus többrétegű laphám figyelhető meg. Az elváltozás a hám szerkezetét tekintve odontogen keratocysta

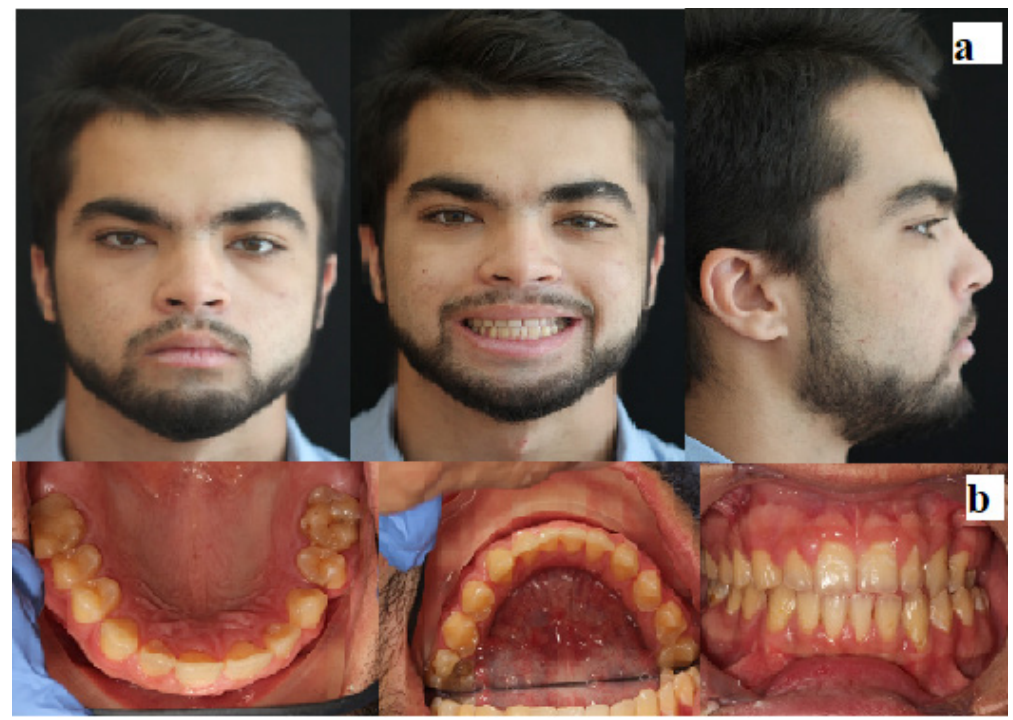


3. táblázat |A Gorlin-Goltz-szindróma diagnózisától kezdődően elvégzett fogorvosi-szájsebészeti beavatkozások időrendi sorrendben

\begin{tabular}{|c|c|}
\hline A kezelés dátuma & A kezelés típusa \\
\hline 2009. 11 . & A páciens első jelentkezése, diagnózis készítése. \\
\hline 2010.01. & $\begin{array}{l}\text { Maxilla- és mandibulacysták dekompressziója } \\
\text { dréncsövekkel a frontalis és molaris területeken. }\end{array}$ \\
\hline 2010.10 . & $\begin{array}{l}\text { Bal angulustáji cystectomia. Impaktált } 3.7 \text {-es és } \\
3.8 \text {-as fogak eltávolítása. A sinusba terjedő bal } \\
\text { maxillacysta cystectomiája és Luc-Caldwell-mú- } \\
\text { tét. A mandibula frontalis területén található } \\
\text { cysták cystectomiája és autológ csontpótlás mel- } \\
\text { lett a jobb oldali molaris területen lévő cysta } \\
\text { cystectomiája. }\end{array}$ \\
\hline
\end{tabular}

2011. 12.

Az alsó, felső rögzített fogszabályozó kezelés elkezdése.

2012. 10. A A felső első impaktált helyzetű kisőrlőfog eltávolítása a fogszabályozó kezelés során.

2014. 02 .

A jobb alsó második molaris fog sculptiója

2015. 10 .

A fogszabályozó készülék eltávolítását követően recidiváló bal oldali mandibulacysta excochleatiója Carnoy-oldat alkalmazásával.

2016-tól félévente Kontroll; az 1.8-as és 2.7-es, 2.8-as impaktált fogak eltávolításra előjegyezve.

merhető. Az ortodonciai intraoralis szakvizsgálat során fogazati recidíva és rossz szájhigiéné figyelhető meg.

A páciens fizikális vizsgálatával és radiológiai eszközökkel diagnosztizált Gorlin-Goltz-szindróma kezelésének összefoglalását mutatja időrendi sorrendben a 3. táblázat.

\section{Megbeszélés}

A Gorlin-Goltz-szindróma autoszomális dominánsan öröklődő, praecancerosus állapottal járó tünetegyüttes, mely jellegzetes fejlődési rendellenességeket is okoz.

A szindróma felismerése fizikális és radiológiai vizsgálattal (extra- és intraoralis röntgenfelvételek, koponya- és mellkasröntgen-felvételek) történik. Az állcsontokban kialakuló odontogen keratocysták az arc eltorzulását, az arc aszimmetriáját okozhatják. Diagnosztikus lehet a fogak mobilitása, korai elvesztése, az állcsont patológiás törése. A pontosabb diagnózis megállapításában és később a sebészi tervezésben nagy szerepet játszik a CBCTfelvételek elemzése [28]. A diagnózis felállítását követően a vérrokonok kivizsgálása is indokolt. Már magzati életkorban, a 10-12. gesztációs héten molekuláris genetikai módszerekkel kimutatható a PTCH-gén mutációja, mely mutáció végül a sejtek tumoros proliferációját okozza [29]. Amennyiben születés után a szindróma diagnosztizálásra került, félévente MR-felvétel javasolt a medulloblastoma kizárására [30]. Ezen túlmenően ajánlott a rendszeres kardioechográfiás vizsgálat [31]. A bőrgyógyászati kontroll félévente ugyancsak javasolt a nagyszámú basaliomák miatt, melyek számuk és nagyságuk miatt akár torzítóak lehetnek. Az állcsontokról készített felvételek elkészítése évente indokolt lehet a recidívák magas százalékban történő előfordulása miatt [12]. Esetünkben a fiú diagnosztizálása a rutin fogszabályozós röntgendiagnosztika során látott állcsonti elváltozásoknak volt köszönhető.

\section{Azállcsontok keratocystái}

Az állcsontok keratocystái kezdetben tünetmentesen növekedhetnek a spongiosa állományban, panaszt csak később okozva. Szövődményként késői fogváltást, patológiás töréseket okozhat. Recidívaaránya nagyon magas (30-60\%) [1].

\section{Börtünetek}

A basaliomák megjelenése általában multiplex, bármely testrészen kialakulhatnak, de a leggyakrabban az arcon, a nyakon és a törzsön jelennek meg. A másik jellegzetes bőrelváltozás a tenyéri és/vagy talpi dyskeratosis [32]. Az ilyen elváltozások azonban esetünkben nem vezettek a fiú kiszűréséhez.

\section{Craniofacialis jellegzetességek}

A szindrómában szenvedők karakterisztikus arcának jellemzői a mandibularis macro- és retrognathia, a széles orrgyök, az erős szemöldök, mely jellemzők részben esetünkben is megfigyelhetők voltak. Jellemző a frontalisan és biparietalisan nagyobb mértékben elődomborodó koponya, jól fejlett margo supraorbitalis [33]. Az ajak-szájpad hasadék nagyobb százalékban (5\%) fordul elő, mint az átlagpopulációban [34].

\section{Vázrendszeri és radiológiai jellegzetességek}

Kalcifikált ovariumfibromák a szindrómás nők felében megtalálhatók [35]. A falx cerebri elmeszesedése már gyermekkorban nagy százalékban (85\%) megfigyelhető. $\mathrm{Az}$ ameloblastoma gyakori megjelenése miatt egyes szerzők javasolják a szindróma diagnózisának kritériumrendszerébe történő felvételét [36]. A betegek több mint felénél az „összeolvadt” vagy osztott bordák kimutathatók, melyek panaszt általában nem okoznak [37].

A basaliomák - melyek a szindróma legjellegzetesebb tünetei közé tartoznak - kezelésének célja a recidíva elkerülése. A basalioma elsődleges terápiája a sebészi excisio. A sebészi ellátást a tumor mérete, száma vagy anatómiai helyzete befolyásolhatja. Gorlin-Goltz-szindróma esetén a terápiás irradiáció kontraindikált [17]. A betegek részére egy új gyógyszeres kezelés jelenthet terápiás megoldást, az úgynevezett 'hedgehog'-inhibitorok. A vismodegib gátolja a transzmembrán fehérjét, mely SMO (smoothened protein) néven ismert, és lefékezi a tumor kialakulásáért felelős Gli-gének expresszióját [38]. Egy metaanalízis [39] eredményei alapján a vismodegib 
alkalmazása esetén kevesebb mellékhatással (gastrointestinalis zavarok, izomfájdalom) kell számolni, mint a sonidegib (LDE225) használata során.

A kezelés típusának megválasztásában a páciens életkorán, a cysta méretén és elhelyezkedésén kívül szerepet játszik a lágyrészek érintettsége és az előzetes kezelések is. Az állcsontcysták kezelésének alapvetően két típusa különíthető el. A konzervatívabb beavatkozások közé sorolható az enucleatio curettage kiegészítésével vagy a nélkül, illetve a marsupialisatio. Az agresszívebb terápiák csoportja magában foglalja a perifériás ostectomiát, a Carnoy-oldat használatát, a krioterápiát vagy az elektrokauterezést, illetve fóként a reszekciót.

A cysták bármilyen módon történő dekompressziója csökkenti a cystán belüli nyomást. A cystán ejtett kis ablak és az ebbe helyezett drén gyorsan kivitelezhető eljárás, melynek során értékes szövettani minta nyerhetó [15]. A marsupialisatiót Pogrel [40] a következőképpen írta le: kb. 1 cm átmérőjű csontablak preparációjával kezd a cystafalon. A cystahám és a szájüregi nyálkahártya összevarrását követően egy állandóan nyitott „zseb” vagy „zacskó” alakul ki, mely lehetővé teszi a cystabennék szabad kiáramlását. Mandibulacysta esetében ez a szájüreg felé, maxilla esetében az arcüreg, az orrüreg vagy a szájüreg irányában is történhet. A publikációkban fellelhető legkorábbi cystakezelési módszer a dekompresszió és a marsupialisatio alkalmazása, mely Partsch I. eljárás néven ismert [41]. Számos szerző [42, 43] azonban ezt nem tartja megfelelő kezelési módszernek. A marsupialisatio során a cystahám részleges eltávolítását végezzük, ami esetleg recidívanövelő kockázat lehet. A beavatkozás nehézségei miatt javasolt kiegészítésként a Carnoy-oldat alkalmazása is. A Peraza és mtsai [44] által ajánlott protokoll szerint 5 percig kell alkalmazni a Carnoy-oldatot kloroform nélkül (ún. módosított Carnoyoldat), aztán múanyag dréncső segítségével dekompreszsziót, cystaszúkítést kell végezni 7-11 hónapig. Ezt követően újra alkalmazzák a Carnoy-keveréket kb. 3 percig, majd enucleatiót, perifériás ostectomiát végeznek, és xenograft csontpótlót helyeznek be. A szerzők 8 éves utánkövetéses vizsgálat során nem tapasztaltak recidívát, fertőzést és állcsonttörést sem. Csupán egy páciens számolt be kényelmetlenségről a dréncső miatt. Amennyiben felmerül a Gorlin-Goltz-szindróma lehetősége, javasolt a Carnoy-oldat bevetése is, melyet a recidív cysták esetén már mi is alkalmaztunk. Az enucleatiót követően kedvező eredménnyel használható a krioterápia. Schmidt és Pogrel [45] standardizált technikája során a cysta enucleatióját követően folyékony nitrogént használtak kétszer 1 percig. A környező szöveteket steril gézzel védték a beavatkozás alatt a fagyási sérülésektől. A standard technika kiegészíthető szimultán csontgraftbehelyezéssel és mucosazárással. Ezzel lerövidíthető a gyógyulási idő, és a patológiás törés veszélye minimálisra csökkenthető. E kezelési módszer másik nagy előnye, hogy a vérzés és a hegesedés csökkenthető.
A cystaüregek augmentációja előnyökkel járhat (például gyorsabb csontgyógyulás), melyeknél több választási lehetőség is felmerül. A saját csont felhasználásának előnyei mellett a donorterület morbiditása ugyan hátrányként említhető [46], ám a csontpótló anyagok (allograftok, xenograftok, alloplasztok) felhasználását a család - részben a költségei miatt is - elutasította. Az odontogen keratocysta kezelése során a legagresszívebb terápia a reszekció. A kiterjedt mandibulareszekció - a kísérő morbiditással együtt - túl radikális terápiának bizonyul, ezért a szerzők többsége egyetért abban, hogy a konzervatívabb terápiák közül érdemes választani.

A recidívák lehetősége miatt nagyon fontos a páciens rendszeres kontrollja, és hogy a predilekciós tényezőket, úgymint az impaktált, retineált, a fogívben sorba nem állítható fogakat elimináljuk, ehhez azonban a beteg részéról rendszeres és kitartó együttmúködésre is szükség lehet a közel tucatnyi szájsebészeti mútét során. Bemutatott esetünknél a három impaktált molaris fog (6. ábra) eltávolítása prevenciós célzattal még hátravan.

A fentebb részletezett eset kapcsán elmondhatjuk, hogy mind a szindróma diagnózisához, mind a terápiájához multidiszciplináris megközelítés, a fogorvos, dentoalveolaris vagy maxillofacialis sebész, bőrgyógyász, neurológus, radiológus és patológus kollégák együttmúködése szülkséges. A szindróma korai felismerésével és rendszeres kontrollal nagyobb eséllyel előzhetők meg a radikális mütéttel járó kezelések, megőrizve így a rágóképességet és az arc esztétikáját, ugyanakkor - mint esetünkben is látható volt - a recidívák miatt a rendszeres kontroll elengedhetetlen.

Anyagi támogatás: A közlemény megírása a PTE ÁOKKutatási Alappályázat No: KA-2018-02 támogatásával készült.

Szerzői munkamegosztás: A munka a szerzők közös érdeme. A cikk végleges változatát mind a négy szerző elolvasta és jóváhagyta.

Érdekeltségek: A szerzőknek nincsenek érdekeltségeik.

\section{Irodalom}

[1] Gorlin RJ, Goltz RW. Multiple naevoid basal-cell epithelioma, jaw cysts and bifid rib. A syndrome. N Engl J Med. 1960; 262: 908-912.

[2] Levanant S, Gorlin R, Fallet S, et al. A two-hit model for developmental defects in Gorlin syndrome. Nature Genet. 1996; 12: 85-87.

[3] Gailani MR. The role of the human homologue of Drosophila patched in sporadic basal cell carcinomas. Nature Genet. 1996; 14: 78-81

[4] Gyenes V, Pataky L, Csiba A. Gorlin-Goltz syndrome. [GorlinGoltz szindróma.] Orv Hetil. 1981; 122: 1967-1969. [Hungarian]

[5] Újpál M, Szabó Gy. Gorlin-Goltz syndrome. [Gorlin-Goltz szindróma.] Fogorv Szle. 1992; 85: 209-212. [Hungarian] 
[6] Gorlin RJ, Cohen MM, Levin LS. Syndromes of the head and neck. Third edition. Oxford University Press, New York, NY, 1992; pp. 365-380.

[7] Kiss T, Liszkay G, Oberna F. Gorlin-Goltz syndrome. [GorlinGoltz-szindróma.] Bőrgyógy Venerol Szle. 2008; 84: 55-59. [Hungarian]

[8] Anehosur V. Gorlin's syndrome - report of a case and management of cystic lesions. J Maxillofac Oral Surg. 2009; 8: 184-187.

[9] Barnes L, Eveson JW, Reichart P, et al. Pathology and genetics of head and neck tumours, WHO classification of tumours. 3rd edition, volume 9. IARC (International Agency for Research on Cancer), Lyon, 2005.

[10] El-Naggar AK, Chan JKC, Grandis JR, et al. WHO classification of head and neck tumours. 4th edition, volume 9. IARC (International Agency for Research on Cancer), Lyon, 2017.

[11] Speight PM, Takata T. New tumour entities in the 4th edition of the World Health Organization classification of head and neck tumours: odontogenic and maxillofacial bone tumours. Virchows Arch. 2017; 472: 331-339.

[12] Stoelinga PJ. Long-term follow-up on keratocysts treated according to a defined protocol. Int J Oral Maxillofac Surg. 2001 30: $14-25$.

[13] Regezi JA. Odontogenic cysts, odontogenic tumors, fibroosseous, and giant cell lesions of the jaws. Mod Pathol. 2002; 15: 331-341.

[14] Khaliq MIU, Shah AA, Ahmad I, et al. Keratocystic odontogenic tumors related to Gorlin-Goltz syndrome: a clinicopathological study. J Oral Biol Craniofac Res. 2016; 6: 93-100.

[15] Brøndum N, Jensen VJ. Recurrence of keratocysts and decompression treatment. A long-term follow-up of forty-four cases. Oral Surg Oral Med Oral Pathol. 1991; 72: 265-269.

[16] Chirapathomsakul D, Sastravaha P. A review of odontogenic keratocysts and the behavior of recurrences. Oral Surg Oral Med Oral Pathol Oral Radiol Endod. 2006; 101: 5-9.

[17] Giuliani M, Grossi GB, Lajolo C, et al. Conservative management of a large odontogenic keratocyst: report of a case and review of the literature. J Oral Maxillofac Surg. 2006; 64: 308316

[18] Morgan TA, Burton CC, Qian F. A retrospective review of treatment of the odontogenic keratocyst. J Oral Maxillofac Surg. 2005; 63: 635-639.

[19] Voorsmit RA, Stoelinga PJ, van Haelst UJ. The management of keratocysts. J Maxillofac Surg. 1981; 9: 228-236.

[20] Stoelinga PW. The treatment of odontogenic keratocysts by excision of the overlying, attached mucosa, enucleation, and treatment of the bony defect with Carnoy solution. J Oral Maxillofac Surg. 2005; 63: 1662-1666.

[21] Pogrel MA. The use of liquid nitrogen cryotherapy in the management of locally aggressive bone lesions. J Oral Maxillofac Surg. 1993; 51: 269-273.

[22] Schmidt BL. Neurosensory changes following cryotherapy. J Oral Maxillofac Surg. 1999; 57: 46.

[23] Blanas N, Freund B, Schwartz M, et al. Systematic review of the treatment and prognosis of the odontogenic keratocyst. Oral Surg Oral Med Oral Pathol Oral Radiol Endod. 2000; 90: 553558 .

[24] Basset-Seguin N, Bissonnette R, Girard C, et al. Consensus recommendations for the treatment of basal cell carcinomas in Gorlin syndrome with topical methylaminolaevulinate-photodynamic therapy. J Eur Acad Dermatol Venereol. 2014; 28: 626-632.

[25] García de Marcos JA, Dean-Ferrer A, Arroyo Rodríguez S, et al. Basal cell nevus syndrome: clinical and genetic diagnosis. Oral Maxillofac Surg. 2009; 13: 225-230.

[26] Yoon J, Apicelli AJ, Pavlopoulos TV, et al. Intracranial regression of an advanced basal cell carcinoma using sonidegib and itraconazole after failure with vismodegib. J Am Acad Dermatol Case Reports 2018; 4: 10-12.
[27] Xie P, Lefrancois P. Efficacy, safety, and comparison of sonic hedgehog inhibitors in basal cell carcinomas: A systematic review and meta-analysis. J Am Acad Dermatol. 2018; 79: 1089-1100.

[28] Szüts J, Németh Zs. Diagnostic and therapeutic aspects of odontoms in maxillofacial surgery. [Odontomák diagnosztikus és terápiás aspektusai a maxillofaciális sebészetben.] Fogorv Szle. 2018; 111: 85-90. [Hungarian]

[29] Manfredi M, Vescovi P, Bonanini M, et al. Naevoid basal cell carcinoma syndrome: a review of the literature. Int J Oral Maxillofac Surg. 2004; 33: 117-124.

[30] Kimonis VE, Goldstein AM, Pastakia B, et al. Clinical manifestations in 105 persons with naevoid basal cell carcinoma syndrome. Am J Med Gen. 1997; 69: 299-308.

[31] Evans DG, Ladusans EJ, Rimmer S, et al. Complications of the naevoid basal cell carcinoma syndrome: results of a population based study. J Med Genet. 1993; 30: 460-464.

[32] Ahn SG, Lim YS, Kim DK, et al. Naevoid basal cell carcinoma syndrome: a retrospective analysis of 33 affected Korean individuals. Int J Oral Maxillofac Surg. 2004; 33: 458-462.

[33] Dahl E, Kreiborg S, Jensen BL. Craniofacial morphology in basal cell carcinoma syndrome. Int J Oral Surg. 1976; 5: 300-310.

[34] Van Dijk E, Neering H. The association of cleft lip and palate with basal cell naevus syndrome. Oral Surg. 1980; 50: 214-216.

[35] Seracchioli R, Bagnoli A, Colombo FM, et al. Conservative treatment of recurrent ovarian fibromas in a young patient affected by Gorlin syndrome. Hum Reprod. 2001; 16: 1261-1263.

[36] Ponti G, Pastorino L, Pollio A. Ameloblastoma: a neglected criterion for nevoid basal cell carcinoma (Gorlin) syndrome. Fam Cancer 2012; 11: 411-418.

[37] Kiss P. (ed.) Atlas of syndromes. [Szindrómaatlasz.] Golden Book Kiadó, Budapest, 2000; pp. 62-63. [Hungarian]

[38] Shahmoradi Z, Andalib F, Siadat AH. Naevoid basal cell carcinoma syndrome. Indian J Dermatol Venereol Leprol. 2010; 76: 71-73.

[39] Shivaswamy KN, Sumathy TK, Shyamprasad AL, et al. Gorlin syndrome or basal cell nevus syndrome (BCNS): a case report. Dermatol Online J. 2010; 16: 6 .

[40] Pogrel MA. Treatment of keratocysts: the case for decompression and marsupialization. J Oral Maxillofac Surg. 2005; 63: 16671673.

[41] Partsch C. Treatment of jaw cysts. [Zur Behandlung der Kieferzysten.] Dtsch Monatsschr Zahnheilk. 1910; 252: 28. [German]

[42] Maurette PE, Jorge J, de Moraes M. Conservative treatment protocol of odontogenic keratocyst: a preliminary study. J Oral Maxillofac Surg. 2006; 64: 379-383.

[43] Bataineh AB, Al Qudah M. Treatment of mandibular odontogenic keratocysts. Oral Surg Oral Med Oral Pathol Oral Radiol Endod. 1998; 86: 42-47.

[44] Peraza A, González L, González N. Outcome after 8 years of a modified conservative treatment experience in keratocystic odontogenic tumor in 5 patients. Oral Maxillofac Surg Cases 2017; 3: $42-47$.

[45] Schmidt BL, Pogrel MA. The use of enucleation and liquid nitrogen cryotherapy in the management of odontogenic keratocysts. J Oral Maxillofac Surg. 2001; 59: 720-725. Discussion: 726-727.

[46] Szabó Gy, Suba Zs, Barabás J, et al. Filling a triple mandibular cyst with different bone substitutes. [Hármas mandibula cysta feltöltése különböző csontpótló anyagokkal.] Quintessenz 2003; 2: 123-125. [Hungarian]

(Gurdán Zsuzsanna dr., Pécs, Dischka Győző u. 5., 7621 e-mail: gurdan.zsuzsanna@pte.hu) 